\title{
Optimization Method of Object Packaging in Planning of Mobile Communication Systems Femtocells
}

\author{
Sielivanov Kostiantyn ${ }^{1}$, \\ Al-Vandavi Saif Ahmed Iskandar ${ }^{2}$ \\ Mykola Moskalets ${ }^{3}$
}

${ }^{1}$ Kharkiv National University of Radio Electronics, 14 Nauky Ave, KharkivUA-61166,Ukraine,sunright@yandex.ua

${ }^{2}$ Kharkiv National University of Radio Electronics, 14 Nauky Ave, KharkivUA-61166,Ukraine,d_ts@nure.ua

${ }^{2}$ Kharkiv National University of Radio Electronics, 14 Nauky Ave, KharkivUA-61166, Ukraine, mykola.moskalets@nure.ua

\begin{abstract}
The problem of placing access points of femtocells in the service area of the mobile base station is considered. A method of optimizing the spatial deployment of femtocells using packaging methods is proposed. Based on the method of joining the single femtocell access points, an algorithm for finding and removing potential nested containers has been built. The proposed method of optimizing the spatial placing of femtocells allows to reduce the time of finding the point of installation in order.
\end{abstract}

Keywords: femtocell, object packaging, planning, access point, container.

\section{INTRODUCTION}

When placing access points for femtocells, different situations arise due to the need to improve the quality of service for subscribers. There are different methods for spatial placement of access points of femtocells for cases of facilitating access of subscribers at the borders of the service areas belonging to a base station (BS) of the mobile network (Fig. 1).

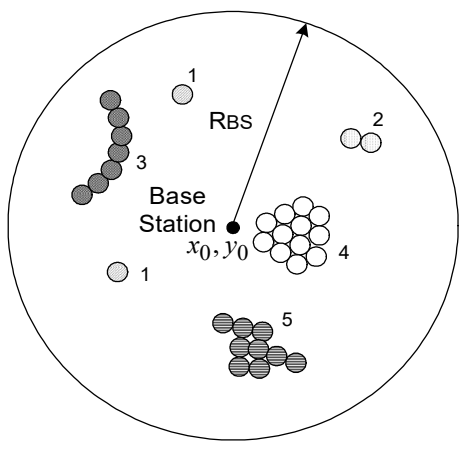

Figure 1. An example of placing femtocells in the BS service area with the coordinates $\left\{x_{0}, y_{0}\right\}$ and radius $R_{B S}$

Fig. 1 shows: 1 - single placing; 2 - a group of two femtocells; 3 - linear placing of femtocells; 4 - a compact group; 5 - a complex structure.

As part of the solution to the problem of constructing a network planning technique using femtocells, currently there is no common model for predicting signal propagation, especially when implementing femtocells in buildings. Thus, there is a problem of placing BS access points of femtocells in the service area, both single objects and objects located in a line on the plane or in the structure of the BS functioning area (Fig. 1).

\section{PROBLEM SOLUTION AND RESULTS}

When planning service areas on the plane, their structure is represented as circles or hexagonal cells. In 3-dimensional space, the area is represented by a circle or a sphere. If we imagine this volume or plane as a container, then there arises a task regarding packaging of objects (femtocells) - axially symmetrical figures of this container [1]. There are a large number of approximate methods of packaging containers with objects of various configurations: genetic algorithms for optimizing packaging of rectangular objects; sequential, i.e. single placing of circles of different radii; methods of packaging cylinders based on Stoyan phi-functions; geometric combinatorics, algebraic methods, etc.

Therefore, the choice of a method is determined by the context of the problem being solved. Among the solutions to such problems, the most appropriate method is a single connection based on the logical choice, which allows to increase the capabilities of the network and is relatively simple.

Based on the selected method of single attachment of objects using logical selection and analysis of the remaining free space of the $i$ th container, an algorithm for searching and deleting of nested containers has been constructed. The proposed method of optimizing the spatial placing of femtocells allows to reduce the search time of the installation point by an order of magnitude.

\section{REFERENCES}

[1] Moskalets N.V. Ispol'zovanie metoda optimizacii upakovki ob`ektov v zadachah planirovanija femtosot mobil'nyh sistem svjazi. Naukove periodichne vidannja "Cistemi upravlinnja, navigaciï ta zv'jazku”. 2017. №2(42). S.185-187.

[2] Popovskij, V. Control and adaptation in telecommunication system: Mathematical foundations [Text] / V. Popovskij , A. Barkalov, L. Titarenko. Tom 94. Springer Science \& Business Media.2011.P.173.

[3] Zaruba, D.V., Ispol'zovanie metodov jevoljucionnoj optimizacii dlja reshenija zadach trehmernoj upakovki [Tekst] / D.Ju. Zaporozhec, Ju.A. Kravchenko // Informatka, vychislitel'naja tehnika i inzhenernoe obrazovanie. 2012. № 2 (9).

[4] Kovalenko, A. A. Upakovka krugovyh cilindrov v cilindricheskij kontejner s uchetom special'nyh ogranichenij povedenija sistemy [Tekst] / A.A. Kovalenko, A. V. Pankratov, T. E. Romanova, P. I. Stecjuk // Zhurnal obchisljuval'noï ta prikladnoï matematiki. 2013. № 1 (111). S. 126-134.

[5] Chekanin V.A., A.V. Chekanin. Modeli konstruirovanija ortogonal'noj upakovki ob’ektov [Tekst] / V.A.Chekanin, A.V. Chekanin // Informacionnye tehnologii i vychislitel'nye sistemy. №2. 2014. S.37-45. 